\title{
The Second Road to Phenomenological Sociology
}

\author{
Patrik Aspers
}

Published online: 27 March 2010

(C) Springer Science+Business Media, LLC 2010

\begin{abstract}
This article outlines and discusses the second road to phenomenology. It is argued that Martin Heidegger's approach to phenomenology represents a radical break with the first, and egological, road paved by Edmund Husserl. The article shows that sociologists who have followed Husserl and Schütz, or more generally have assumed the egological approach, in fact operate with a non-sociological starting point. Husserl brackets the lifeworld in order to get to true knowledge. In his view, ego tries to reach out to other egos, and social relations is a consequence of egos attempts. Heidegger, in contrast, argues that our lifeworld is the starting point of any knowledge, and this means that man is essentially constituted as being together with other men.
\end{abstract}

\section{Keywords Phenomenology· Sociology · Socioontology}

Few social scientists have taken the direct route to phenomenology. They have instead been lead, guided and accompanied by others, whose works have been like bridges of knowledge leading back to the original sources. The work that has spawned the interest among social scientists in phenomenology the famous work The Social Construction of Reality (Berger 1970:15; Berger and Luckmann 1991), by Peter Berger and Thomas Luckmann has also profoundly affected the social sciences, and above all sociology. It is primarily through their work that social scientists have come to appreciate another Austrian, namely Alfred Schütz (1899-1959). And through Schütz, some have travelled the road all the way back to the father of phenomenology, the German philosopher Edmund Husserl

P. Aspers $(\square)$

Department of Sociology, Stockholm University,

10691 Stockholm, Sweden

e-mail: patrik.aspers@sociology.su.se
(1859-1938). Thus, the first, and by far the most wellknown, road to phenomenology goes from Berger to Schütz and ends with Husserl.

Clearly, the idea of social construction has been crucial for the influence of phenomenological sociology. It was, if I am correct, in a review by Peter Berger that the notion with the meaning it has today was first introduced. In the review of "Truth in the Religions: A Sociological and Psychological Approach" by W. Montgomery Watt, Berger used the phrase "the social construction of reality" (1964:292). Today, more than 40 years after this term was coined, it is in fashion to call a paper, dissertation or a book "The Social Construction of...”

It would be easy to continue, and in a text like this only discuss Peter Berger's different contributions to sociology. We would then, however, have to cover much ground, and obviously not restrict our investigation to the first road of phenomenology. Such a study would take us, for example, from phenomenology, to Max Weber, to the role of society in man, to capitalism and religion. More specifically, I would like to mention the role of values in society, and the centrality of conflicting values in modern society (Berger 1997). Berger is thus a Gesellschaftsforscher, who has analyzed our contemporary social life in a Weberian spirit, taking the different life-spheres into account. It is to me clear that Berger's work points at the importance of meaning, and meaning production. Religion plays here a central role (Berger 1969), and also capitalism is a large theme (Berger 1986) in his list of publications. His work is, hence, deeply rooted in the European tradition of sociology, with a clear focus on the most central concept in the social sciences, meaning.

In this article I will neither review nor discuss Berger's work in detail, instead I will do what I think is the best way to pay tribute to a thinker (Heidegger 1985:6), namely a kind of 
Auseinandersetzung ("confrontation") with the central idea of the first - the epistemic — road to phenomenology.

This article takes the reader on a tour along the second road to phenomenology, which will lead us to the German phenomenologist and philosopher Martin Heidegger (18891976). Heidegger worked close together with Husserl, but he gradually developed his own approach (Frede 2006). More specifically, I shall claim that Heidegger's ontological approach points at a radically sociological starting point compared with the Cartesian epistemic-egological approach that has come to dominate the social sciences. There are two important, though related, distinctions to be made to clarify the two different roads; one between epistemology and ontology, and one between egology and sociology. As shall be clear, these two are interrelated. I begin by discussing the first road to phenomenology. I shall focus on the defining characteristics, and in the second step, critically discuss it.

\section{The First Road to Phenomenology: Egological Epistemology}

The first road to phenomenology is well-known. When talking to people in the social sciences who have a serious interest into phenomenology, their story is often identical. After having read Berger and Luckmann, they got interested in Schütz, and they may even have looked at or studied the works of Husserl. Husserl will be the example of the Cartesian epistemic position because of the clarity of his presentation. My argument is that the discussion of Heidegger will uncover the paradigmatic assumptions (Kuhn 1962) of the social sciences that are taken for granted.

Phenomenology can broadly be defined as the study of "that what appears". To Husserl, who wanted to establish a new scientific foundation based on phenomenology, the central question was epistemic, as it had to do with the problem of how the Cartesian ego would gain knowledge about the world. His starting point, however, was man living in the real life - the lifeworld. Husserl argues that each person lives in a world, in the natural attitude, as a "human person living among others in the world" (Husserl 1989:411). It is the world I perceive: I hear the breaking waves, I see my neighbor go to work, and I talk to my family; this world is immediately there for me, and I need not do anything but to take part in this world (cf. Husserl 1962:91-93). In this attitude people take, for example, the social surrounding, houses, values and social life, including one's friends and the court of appeal, for granted. Husserl, however, argues that this world cannot serve as the foundation of true knowledge. This basic idea led Husserl into a major project of establishing a true base of knowledge.
Phenomenology is a descriptive science, which in the end results in an eidetic science, or a universal ontology, as it is the "science of the transcendental inter-subjectivity or universum of fact" (Husserl 1945:702). This starting point aims at generating an ontology, a formal ontology, upon which all regional ontologies, for example of the empirical sciences, can be based (Wolf 1984:1195). To address this issue, Husserl readdresses the Kantian question of how knowledge is possible (Zahavi 2003:8). To follow this path, Husserl could not take anything of what is considered as true by ordinary people, or by the scientists and philosophers, for granted; everything has to be put into question. He follows Descartes and asks if there is a justification for his experience, and he answers: "No! I have based my previous life and scientific activities on it without even justifying it" (Husserl 1981:318). Husserl's study aims at creating a new beginning, a "radical beginning", or "first philosophy" as he (1962:19-20) calls it. Husserl explains his approach: "transcendental phenomenology is not a theory ...it is a science founded in itself...that stands absolutely on its own ground" (Husserl 1962:13).

Husserl claims that to accomplish true knowledge, one must perform the psychological reduction, which puts the world as we know it in bracket, and which leaves two parts, the way things are experienced ("the noetic") and what is experienced ("the noematic"). This means that the study is epistemic in its nature, starting with the question of what there is, based on the idea of a pure ego (the knowing subject).

\section{Bracketing the Real World}

It must always be remembered that the reductions proposed by Husserl start from the experiences of the real world (cf. Husserl 1981:337), and these experiences are analyzed from within the transcendental sphere, not the natural attitude (Husserl 1980:20). He proposes the method of reduction, and this implies bracketing of the natural attitude. This bracketing includes, man, personality, gender, history, including all sciences (Husserl 1962:155-167). The various sciences are bracketed since they lack the grounding that can be used as a stepping-stone for further analysis of knowledge; they lack the ability to reflect on their own foundation. Consequently, the theoretical results of empirical sciences, cannot be assimilated by phenomenology (Husserl 1962:56-57). Only after the transcendental reduction is performed, which is done, and can only be done, in the first person, the ego is able see the essential being, and this seeing is based on pure intuition (e.g., Husserl 1962:174-175).

The transcendental (Cartesian) reduction does not only bracket the real world, but the existence of souls as well. 
Husserl says that it provides the foundation for the existence of subjectivity and that "which makes the world" ([1929] 1945: 701). Through this reduction the Ego pole is reached. Bracketing represents a shift from "external experiencing of the world...into transcendental subjectivity" (Husserl 1997:245). It means that the world, including me as a person living among others is no longer the center of attention; it is bracketed, and the center of attention is the world as mere phenomenon (Husserl 1997:246).

The epistemic relation is clearly expressed by Husserl; the world is experienced and known by the transcendental subject in isolation - the ego. It follows that the ego is the constituting pole of both everyday knowledge and the knowledge of the objective world of science that is built on that everyday knowledge (Husserl 1960:§40, 59). The mental becomes the foundation, rather than the external world of objects, as in the objectivistic tradition. This is a radical shift, and Husserl refers to this as a "Copernican turn" (Husserl 1960:§61).

Phenomenology, according to Husserl appears so far to be an activity of egos in solitude. But Husserl is, in addition, outlining a transcendental "community" of identical egos. What sociologists see as the problem of the social is also by Husserl seen as central problem, but it is clearly a derivative question, and social communities are "personalities of a higher order" (Husserl 1960:132). This is the grounding of what may be termed egology. This is no interpretation as he says: "This universal concrete ontology (or universal and concrete theory of science theory of science - this concrete logic of being) [transcendental phenomenology] would therefore be the intrinsically first universe of science grounded on an absolute foundation. In respect to order, the intrinsically first of the philosophical disciplines would be the 'solipsistically' reduced 'egology', the egology of the primordially reduced ego. Then only would come intersubjective phenomenology, which is founded on that discipline" (Husserl 1960:155).

In other words, this egological approach assumes a subject (ego) who somehow reaches out and tries to understand everything, its environment, including others and what we call social life. It is, in my view, a fictitious approach as it turns its back on every-day knowledge, and Husserl argues, "Daily practical living is naive. It is immersion in the already-given world, whether it be experiencing, or thinking, or valuing, or acting...Nor is it otherwise in the positive sciences. They are naivetés of a higher level. They are products of an ingenious theoretical technique" (Husserl 1960:152-3). That this is a non-social starting point is thus clear, especially in the fifth Cartesian meditation (Husserl 1960). It is, moreover, an approach that is "first of all monadic, and then intermonadic" (Husserl 1960:156). Its social science offspring is the knowing and acting subject, though this subject is often located in the lifeworld. The egological approach is a historically created doctrine (Heidegger 2001b:22-23) of man as an ego, which has its root in Greek thinking, perpetuated by Christian ideas, and which Descartes refined. This idea was taken over as a tacit foundation by the social sciences.

\section{The Schützian Turn to Sociology}

Husserl did not show much direct interest in sociology, his ambition was to provide a foundation for all sciences, including sociology. Despite this, the phenomenological ideas of Husserl were one main source of inspiration for Alfred Schütz. Though he acknowledges the centrality of phenomenology, Schütz clearly says that he does not follow Husserl: "as we proceed to our study of the social world, we abandon the strictly phenomenological method. [...] The object we shall be studying, therefore, is the human being who is looking at the world from within the natural attitude" (Schütz 1976:97-98, cf., 43-44). According to Schütz, the starting point of the social sciences is, the "intentional conscious experiences directed toward the other self" (Schütz 1976:144). This approach is clearly oriented to the mental side of human life, but it says less on human practice.

Schütz, in his attempt to develop a full theory of action, takes theory of meaning from phenomenology and adds it to Max Weber's theory of action. Weber's idea of sociology refers to actions that are oriented to others, but this is merely a sub-category of action (Weber 1978). This is clear from the following quotation from Weber. "We shall speak of 'action' insofar as the acting individual attaches a subjective meaning to his behavior-be it overt or covert, omission or acquiescence. Action is 'social' insofar as its subjective meaning takes into account of the behavior of others and is thereby oriented to its course" (Weber 1978:4). It should be acknowledged that from a logical point of view, Schütz makes a valid move: to combine the egological starting point of Husserl's theory of knowledge and meaning with Weber's non-social (and essentially egological) starting point.

Husserl's work is the condition for any later phenomenology, but it has also created a somewhat strange gulf between philosophical phenomenology and sociological phenomenology, as the latter has tried to stay outside of the transcendental sphere, following Schütz who abandons the "strictly phenomenological method". Peter Berger has taken up the Schützian approach and says that the "Lebenswelt" is the world "in der wir, zusammen mit anderen Menschen unseren 'normalen' Tätigkeiten nachgehen" (Berger 1970:15), and it is the reality of the lifeworld that is the "natural" environment for us. I have in my own work built on this sociological tradition of phenomenology 
with its roots in Husserl, Schütz and Berger and Luckmann, but taking it in a more empirical direction (Aspers 2006, 2009), which lead me to develop what I call empirical phenomenology. Though it may be too early to finally judge the value of this approach, not the least as Husserl's main contribution to the discussion of the lifeworld has only recently been published (Husserl 2008), it looks as if the old Cartesian approach holds a firm grip of phenomenological researchers (Moran 2000; Zahavi 2003).

Most of these approaches have nonetheless maintained a more or less explicit idea of an egology. They have come to stress the mental, and essentially followed the tradition of sociology to start with the idea of man as something that is not inherently social; man becomes, and is capable of being, social, but is not socially constituted. If we follow Husserl and Weber, meaning is individually constituted and only occasionally social. This bias in the social sciences, though it is often only a bias when it comes to the assumptions, towards Husserlian egology is not necessary. However, it is frequently the case that thinkers reject Heidegger and defend the "subjective" or "egological" starting point. Emmanuel Levinas speaks of the "ontological root of solitude", which means that he "repudiate[s] the Heideggerian conception that views solitude in the midst of a prior relationship with the other" (Levinas 1987:40-41). In fact, had social science phenomenologists also studied Heidegger, we could have been better off.

\section{The Second Road to Phenomenology: Social Ontology}

Heidegger's phenomenology can fruitfully be read as a critique of Husserl's idea of phenomenology. Both, however, claim to have defined phenomenology. Heidegger defines philosophy as universal phenomenological ontology (Heidegger 2001b:436), which means that the point of departure is the human being living in society, and not an externally existing world to be discovered by solitary egos.

The ontological question, Heidegger argues, must start with who we are. The epistemic approach, in contrast, presumes a distinction between man and the world "out there". Thus, the distinction between a subject that is there to detect the world in the epistemic tradition already assumes an ontology (Heidegger 2001b:58-66). However, the main problem, Heidegger says, is not ontology, but to find a ground for any ontology (Heidegger 2001b:68). Heidegger puts man at the centre of the "creation" of ontology, instead of posing the Cartesian question of how I - the ego - can get to know the "externally existing world" in an true way by a process of reduction, as suggested by Husserl. This has been noted by others: "the strategy of Being and Time...is to reverse the Cartesian tradition by making the individual subject somehow dependent upon shared social practices" (Dreyfus 1991:14; Schmid 2009).

To Heidegger, the starting point is our everyday life (Heidegger 2001b:28-31) with its practices. Heidegger argues that we are part of this world, and it follows that we cannot do science as if we were not part of it. We are in the world, and it is because of this that he talk of Dasein ["being-there"] (Heidegger 2001b:15). Dasein is a being that is always mine - it is me (Heidegger 1979:325), and I cannot escape being there (Dasein).

Heidegger's hermeneutical phenomenology is radically different from Husserl's transcendental phenomenology. It is in this light that Heidegger argues that Husserl aims to solve a construed problem, which itself is the result of the epochémethod developed by Husserl. Heidegger says that the detached subject ("Rumpsubjekt") in the tradition of Descartes and Leibniz is unable to communicate with others. Husserl has tried to solve this by imposing "empathy" between the different ego-poles (Heidegger 2001b:140). Heidegger's approach, moreover, is entirely different from what Mead (1934:221-226) represents. Also Mead essentially represents an epistemic-egological perspective when compared with Heidegger (Malhotra 1987). Heidegger's approach — which perhaps is obvious - consequently stands in contrast to the "thinking" ego-centered approaches, like rational choice (cf. Moran 2000:238).

Heidegger proposes an hermeneutic starting point that accounts for our historically contingent positioning and knowledge (Heidegger 1994:109-114). We as human beings, or what Heidegger calls Dasein, are encapsulated in a structure of concepts, which has to be the focus of a deconstruction ("Abbau"), or taking apart, to understand Dasein (Heidegger 1994:117). According to Heidegger, any question must necessarily departure from "what we know" which is knowledge rooted in the lifeworld. He acknowledges that this lifeworld is a historical product of human culture, which is to say that our logic and ontology are products of the past (Heidegger 1994:113). The study is, as it were, affected by the point of view which we have, and thus conditioned by history (Heidegger 1994:115), reflecting the importance of temporality. Heidegger presents a holism in which the constitution of man must, on the one hand, be understood in relation to "tools" (Zeuge) that we use. Humans, however, have a form of being that is more profound than "objects;" they have a special role as the centre of constitution of the world. Let us look closer at these two relations.

To Heidegger, any knowledge must be grounded in man as living among other men, as this is constitutive (Heidegger 2001b:53-60). This is the relation between Dasein and das Man (the others). What does the idea of das Man imply? Man is from the very "beginning" part of a larger whole, the world, and never alone, others are always 
there. This is a strong proposal. Also when one or more others are not there (presence in the same spatio-temporal moment), they are there, as, for example, when someone is missed. This relation to others is constitutive, and also when Dasein is alone, the others are existentially there. Obviously, we also meet others directly, when they or we are doing something, for example, at work (Heidegger 2001b). They are, of course, noticeable in their indirect presence, in the form of tools that are made for man, and the table that is made by someone, the umbrella that is forgotten by someone, in addition to the direct presence of others (Heidegger 1979:326-329).

An important aspect of Heidegger's analysis of man, which he indeed shares with Nietzsche (Aspers 2007) is the insight that man is not alone; he is essentially "social." In fact, man is so much "together" and conditioned by others that it is even hard to be alone. No metaphysical reductions can undo this. Furthermore, this is indeed a different problem that the "existential" problem of Kierkegaard; the problem of how to come closer to God (and perhaps to one another). This problem is merely an issue given the ontological constitution of man.

It is important to note that being together in the world is not the same as being together with stones. Objects are Vorhanden, there, but in another sense. Though also stones and the see are part of the world, man cannot be with them. Man can only be with others, i.e., other men (which Heidegger calls Mitsein), which is a special ontological relation that characterizes man (Heidegger 2001b:137). Mitsein refers to others in a special form; a man who uses the boat at the lake, and is not standing in the same as ontological relation as the boat to me.

The Dasein-Das Man relation is hence an essential relation, and one may say that man is man because one has taken over the institutions and knowledge of one's predecessors. Man's activities are directly, as in activities by a supplier to a buyer, or indirectly, as when one reads a journal article, related to others (one reads a journal article as "one" reads it, talks as one does, to take a few examples). The socially constructed norms and activities can never be excluded from how man acts, if so man would no longer be man. Dasein is in-the-world (Heidegger 2001a:138) doing things with others, for others, in the position of others, and with tools and knowledge generated by others, orienting to the norms of man. This ontological constitution, hence, is social. We may thus speak of an socioontological consititution, or for short: socioontology.

\section{The Socially Primed Man}

It is here not possible to elaborate on the full meaning of Heidegger's project (see for example Dreyfus 1991;
Safranski 1994), but one thing should be perfectly clear: as one part of the constitution of man, i.e., what one cannot think away, is other men. We are now ready to pose the inevitable question: what, if any, are the consequences of Heidegger's approach for the social sciences? According to Peter Berger and Thomas Luckmann, man cannot be analyzed as something that is non-social. Any making of institutions and order is conditioned by man, according to Heidegger. We have seen that Husserl, Schütz and Weber in fact do not start with a social man. The egological approach, thus, penetrates sociology much deeper than merely being the ground rational choice or the idea of economic man.

What I have proposed is an ontological foundation based on the socioontology of Martin Heidegger. This foundation is not to be found in biological (Park 1936) or psychological traits. It is man's relation to others, direct and indirectly (through das Man), which constitutes him; "biology" and "psychology" are more like modes of being and not first principles of knowledge.

The critique of Husserl and other followers of the Cartesian tradition - which is the foundation of economic theory, rational choice, and Weberian sociology-is that man does not have to solve all problems from within the egological house. This egological approach creates quasi problems, such as prisoners' dilemma, the emergence of the state and yet other problems.

An insight of the more sociological starting point is that man is not born existentially free as his existential relation to the world is contingent upon others. This idea is clear in the writings of Nietzsche, who presents an analysis of how man is "embedded" in a social world, than presenting a normative view of an Übermensch (Aspers 2007). Put in another language: man cannot escape this situation in which he is thrown (Heidegger 2001b). Man is social, and Heidegger suggests that man is indeed more social than sociologists have assumed. Man is ontologically oversocialized (Wrong 1961), which is not to deny that man is ontically undersocialized.

The central argument in this paper is that the social sciences have not taken what I have called the second route to phenomenology. This route takes us to its starting point, were we find the works of Martin Heidegger. Though this road is not directly visible to most social sciences, as there are few links between Heidegger and the social sciences, I have tried to show that there is a fruitful road to establish a social foundation for the social sciences. Of the two kinds of phenomenology: the Cartesian egology and Heidegger's socioontology, it is, unfortunately, the first one that was taken by the founding fathers of sociology, most notably Weber. I have not shown what perhaps is too evident, namely that neoclassical theory starts with egological approach, and claims this to be the correct way of reasoning 
for almost any field of research (Becker 1991). This, however, can only be done against the background of a taken for granted lifeworld.

Though few sociologists have followed Husserl's Cartesian and monadological ideas for establishing a base of knowledge; the egological starting point has become established in sociology. The Weberian idea and definition of social action, which so to speak occasionally is added to a non-social life has given sociology, in my view, the false starting point. More generally, sociology, in this respect, is only something that has been added on to economics, as in the case of Weber. It is also this assumption that has remained, though tacit, in much of social science thinking.

This egological assumption in the social sciences is at least 100 years old, and there is clearly sooner than later that a new start must come. This paper has not in detail outlined such an alternative, only hinted to what could be a new beginning, taking off from what is the second road to phenomenology, namely the ideas developed by Martin Heidegger. His socioontology is an interesting step towards a truly social foundation of the social sciences.

\section{Further Reading}

Aspers, P. 2006. Markets in fashion, a phenomenological approach. London: Routledge.

Aspers, P. 2007. Nietzsche's sociology. Sociological Forum, 22, 474499.

Aspers, P. 2009. Empirical phenomenology: A qualitative research approach (The Cologne seminars). Indo-Pacific Journal of Phenomenology 9.

Becker, G. 1991. A treatise on the family. Cambridge: Harvard University Press.

Berger, P. 1964. Review of 'Truth in the Religions: A Sociological and Psychological Approach' by W. Montgomery Watt. American Sociological Review, 29, 291-292.

Berger, P. 1969. A rumor of angels: Modern society and the rediscovery of the supernatural. New York: Doubleday \& Company Inc.

Berger, P. 1970. Auf den Spuren der Engel: Die moderne Gesellschaft und die Wiederentdeckung der Transzedens. Frankfurt am Main: Fischer.

Berger, P. 1997. Die Bewältigung der Sinnkrise eine zentrale Herausforderung für moderne Gesellschaften. In W. Weidenfeld (Ed.), Dialog der Kulturen: Orientierungssuche des Westenszwischen gesellschaftlicher Sinnkrise und globaler Zivilization (pp. 27-32). Gütersloh: Verlag Bertelsmann Stiftung.

Berger, P. L. 1986. The capitalist revolution. New York: Basic Books.

Berger, P., \& Luckmann, T. 1991. The social construction of reality, a treatise in the sociology of knowledge. London: Penguin Books.

Dreyfus, H. 1991. Being-in-the-world, a commentary on heidegger's being and time, division 1. Cambridge: The MIT.

Frede, D. 2006. The question of being: Heidegger's project. In The Cambridge Companion to Heidegger (pp. 42-69). Cambridge: Cambridge University Press.

Heidegger, M. 1979. Prolegomena zur Geschichte des Zeitrbegriffs, Gesamtausgabe, Abteilung II, Vorelesungen 1923-1944. Frankfurt am Main: Vittorio Klostermann.
Heidegger, M. 1985. Nietzsche: Der Wille zur Macht als Kunst, Gesamtausgabe, II Abteilung: Vorlesungen 1923-1944, Band 43. Frankfurt am Main: Vittorio Klostermann.

Heidegger, M. 1994. Einführung in die phänomenologische Forschung, Gesamtausgabe, II. Abteilung: Vorlesungen 1919-1944, Band 17. Frankfurt am Main: Vittorio Klostermann.

Heidegger, M. 2001a. Einleitung in die Philosophie, Gesamtausgabe, II Abteilung: Vorlesungen, Band 27. Frankfurt am Main: Vittorio Klostermann.

Heidegger, M. 2001b. Sein und Zeit. Tübingen: Max Niemeyer Verlag.

Husserl, E. 1945. Phenomenology. In Encyclopedia Britannica (pp. 699-702). Chicago: Encyclopedia Britannica.

Husserl, E. 1960. Cartesian meditations, an introduction to phenomenology. Haag: Martinus Nijhoff.

Husserl, E. 1962. Ideas, general introduction to pure phenomenology, book I. New York: Collier Books.

Husserl, E. 1980. Ideas, pertaining to a pure phenomenology and to a phenomneological philopophy, book III, phenomenology and the foundations of the sciences. The Hauge: Martinus Nijhoff.

Husserl, E. 1981. Phenomenology and anthropology. In P. McCormick \& F. Elliston (Eds.), Edmund Husserl, shorter works (pp. 315323). Notre Dame: University of Notre Dame Press.

Husserl, E. 1989. Ideas pertaining to a pure phenomenology and to a phenomenological philosophy. Book II: Studies in the phenomenology of constitution. Dordrecht: Kluwer.

Husserl, E. 1997. The Amsterdam Lectures on Phenomenological Psychology. In Edmund Husserl Collected Works, Vol. VI: Edmund Husserl, Psychological and Transcendental Phenomenology and the Confrontation with Heidegger (1927-1931) (pp. 213-253). Dordrech: Kluwer.

Husserl, E. 2008. Die Lebenswelt. Auslegungen der vorgegebenen Welt und ihrer Konstitution. Texte aus dem Nachlass (19161937): Husserliana LXXXII. Dordrecht: Springer.

Kuhn, T. 1962. The structure of scientific revolutions. Chicago: Chicago University Press.

Levinas, E. 1987. Time and the other. Pittsburgh: Duquesne University Press.

Malhotra, V. 1987. A comparison of mead's 'self' and heidegger's 'dasein': Toward a regrounding of social psychology. Human Studies, 10, 357-382.

Mead, G. 1934. Mind, self, and society, from the standpoint of a social behaviorist. Chicago: Chicago University Press.

Moran, D. 2000. Introduction to phenomenology. London: Routledge.

Park, R. E. 1936. Human ecology. The American Journal of Sociology, 42, 1-15.

Safranski, R. 1994. Ein Meister aus Deutschland, Heidegger und seine Zeit. München: Carl Hanser Verlag.

Schmid, H. B. 2009. Plural action, essays in philosophy and social science. Dordrecht: Springer.

Schütz, A. 1976. The phenomenology of the social world. London: Heineman Educational Books.

Weber, M. 1978. Economy and society, an outline of interpretive sociology. Berkeley: University of California Press.

Wrong, D. 1961. The oversocilized conception of man in society. American Sociological Review, 26, 183-193.

Zahavi, D. 2003. Husserl's phenomenology. Stanford: Stanford University Press.

Patrik Aspers is Associate Professor of Sociology at Stockholm University. His most recent book is Orderly Fashion, A Sociology of Markets (Princeton University Press 2010). He was for many years at the MPIfG in Cologne, researching markets. His main fields of interest are sociological theory and the basic questions of social sciences, and economic sociology, especially markets. He is currently working on the sociology of Martin Heidegger. 